\title{
Financial Sustainability of Nonprofit Organizations: Determinants of Fundraising Campaigns on Donation Intention
}

\author{
Hayoung PARK*, Yooncheong CHO**
}

Received: February 13, 2020 Revised: February 28, 2020 Accepted: March 05, 2020.

\begin{abstract}
Purpose: As nonprofit organizations have made strides in international development, ensuring financial resources has become pivotal to determine what nonprofits strive for and how they perform with the budget generated without efforts for profit-making. The purpose of this research aims to investigate the determinants of donation intention that are affected by television fundraising campaigns in order to improve financial sustainability. This study applied the effects of emotional sympathy, economic value, accountability, relevance, and sustainability on donation intention. Research design, data, and methodology: This study collected data via an online survey by classifying respondents based on donation experiences and applied statistical analyses such as factor analysis, regression, and ANOVA. This study selected television fundraising campaigns aligned with criteria of the Sustainable Development Goals (SDGs). Results: The results of this study showed that emotional sympathy was a dominant variable regardless of previous donation experiences, while economic value was significant for inexperienced donors. Conclusions: The results provide implications to nonprofit organizations for fundraising as to what aspects need to be addressed in order to draw donors' motivation for giving behavior. Given efforts for successful implementation of development agenda, it is fundamental to establish financial sustainability of nonprofit organizations and build up public awareness.
\end{abstract}

Keyword: Nonprofit, Financial Sustainability, Donation, Campaigns

JEL Classification Code: L31, M37, M30

\section{Introduction}

Nonprofit organizations determine significant impact on policy processes in terms of global governance, since they are capable of dealing with both market and non-market functions, such as contributing to economic development, delivering social services, and promoting human rights (Keith \& Roger, 1993; Wolch, 1990). Nonprofit organizations also have reached a point where they can provide services beyond the limits of government and public institutions. How nonprofit organizations provide better services has critically relied on the magnitude of voluntary participation by donors that delivers a significant

*Graduate, KDI School of Public Policy and Management, Korea. Email: amooti@kdis.ac.kr

${ }^{* *}$ Corresponding Author: Professor, KDI School of Public Policy and Management, Korea. Email: ycho@kdischool.ac.kr

(c) Copyright: Korean Distribution Science Association (KODISA)

This is an Open Access article distributed under the terms of the Creative Commons Attribution NonCommercial License (https://creativecommons.org/licenses/by-nc/4.0/) which permits unrestricted noncommercial use, distribution, and reproduction in any medium, provided the original work is properly cited. amount of financial resources. In order to effectively solicit supports from the public, it is important to understand how potential donors receive fundraising messages from nonprofit organizations.

To perform its organizational purposes, ensuring financial resources with adequate fundraising strategies has become important issues for nonprofit organizations and international development sectors. In order to build up financial competence, nonprofit organizations strive to raise donation behavior from individual donors who are voluntarily willing to join, which provides the basis of the organizational budget (Casey, 2016). Regarding the features of fundraising, earlier fundraising activities applied many theories and strategies from the aspect of marketing, which need to be analyzed based on the characteristics of nonprofit organizations (Lindahl \& Conley, 2002). Fundraising strategies have affected not only the amount of donations but the way the public perceives global poverty (Brooker et al., 2015). According to Brooker et al. (2015), if people could not understand the necessity of what nonprofit organizations try to achieve, it would ultimately cause 
lower participation from the public. Thus, setting strategic approaches to promote donation behavior induces sustainable competences through fundraising as it is one of the prioritized activities in the nonprofit sector.

The purpose of this study is to investigate the factors of donation intention in response to television fundraising campaigns of nonprofit organizations. In particular, this study focuses on television campaigns as important intermediary channels in the process of individual donor acquisition (Yörük, 2010). In order to classify different topics of fundraising campaigns, this study selected cases of natural disaster, hunger, diseases, lack of education, and sanitation in line with the criteria of the Sustainable Development Goals (SDGs). Previous studies rarely examined the effects of television fundraising campaign on giving behavior in line with the global development agenda. Considering the gap of existing literature, this study brings its uniqueness by addressing intention of giving behavior towards specific issues of global development aligned with SDGs.

As nonprofit organizations are prominent players overlapping with SDGs such as social welfare, environmental conservation, health, education, and human rights, successful achievement of the goals can depend on the role of nonprofits leveraging their capacities (Salamon $\&$ Haddock, 2015). The following research questions have been developed to identify the determinants on donation intentions in relation to television fundraising campaigns of nonprofit organizations: how likely are individuals willing to donate based on perceived emotional sympathy, economic value of donation, organizational accountability, relevance of the program, and sustainability for beneficiaries? This study measured questions by classifying respondents based on donor experiences. Furthermore, research questions regarding effects on donation intention are also corresponding to the purposes of SDGs, including SDG 1 (no poverty), SDG 2 (zero hunger), SDG 3 (good health and well-being), SDG 4 (quality education), and SDG 6 (clean water and sanitation).

\section{Literature Review}

\subsection{Nonprofit Fundraising}

In terms of nonprofit organizations, fundraising can no longer be regarded as a request for monetary assistance, but the exchange of values and expectation, which meets the donors' needs (Andreasen \& Kotler, 2008). Concerning the objectives of nonprofits, it is often hard to be described in commercial ways, even though the goal of fundraising marketing seems like "making a profit" (Teri, 2001). This means that there are a number of factors to consider when setting up a fundraising strategy in nonprofit sectors, bringing a different approach compared to for-profit organizations, which simply aims at the economic gain. Therefore, on the side of nonprofit organizations, fundraising is a process of ensuring validity by not only raising funds to carry out organizational missions but also convincing the necessity of their activities (Čačija, 2013).

When it comes to the outcomes of fundraising, existing studies have tried to find out explaining variables that determine donation intention and donation behavior. Considering photographic images used for fundraising to demonstrate the poverty, images that arouse sadness to the viewer are more likely to show charitable behavior (Baberini, Coleman, Solvic, \& Västfjäll, 2015). When people come across advertisements that evoke empathetic feelings, it is expected to respond positively to donation request in favor of nonprofit organization (Benett, 2015). While charity appeals deliver positive attitude for the viewers toward organizations, it turned out hard to predict donation behavior (Erlandsson, Nilsson, \& Västfjäll, 2018). After recognizing the problem situation through fundraising message, people communicate with nonprofit organization to decide their donation behavior (Zheng \& McKeever, 2016). As relationships grow through interpersonal communication with nonprofit organizations, this encourages donors to engage in more donations by maintaining a high level of trust (Waters, 2011). Accordingly, internal controls and efforts to increase organizational accountability have a positive impact on donors to perceive the quality of services provided by nonprofits (Becker, 2018).

\subsection{Television Fundraising Campaign}

Krugman (1965) asserted that television advertisement induces a buying behavior by introducing a new perspective of a product while people are exposed to the content. In terms of nonprofit fundraising, television campaign has become one of the important tools to solicit financial assistance as well as to create the organizational brand (Aldrich, 2004). Since the World Vision began to air a type of documentary program showing the reality of the postwar poverty to promote donations in 1972 (Waters, 1998), many nonprofit organizations have evolved it as an important channel to demonstrate the need in poverty and call an action. Especially, by drawing prompt response from the viewers, television fundraising is efficient to raise emergency funds for cases of natural disaster by convincing the urgency of the situations (Aldrich, 2004). When broadcasting a fundraising campaign, it is shown more effective in encouraging donation behaviors that a nonprofit organization proposes a specific amount required to solve the problems (Reiley \& Samek, 2018). 


\subsection{Donation Intention}

Previous studies have applied intention (Bae, Kim, \& Oh, 2019; Phan, Nguyen, \& Bui, 2019) Given the voluntary nature of nonprofits, it is also important to inform the public of organizational goals and activities by drawing participation from the public (Leighann, Francois, \& Anahit, 2012). In recent years, individual donations collected through fundraising activities have been one of the main funding sources for nonprofit organizations (Srnka, Grohs, $\&$ Eckler, 2003). This relates to the key characteristic of the nonprofit sector, "voluntary," for the financial capacity of organizations depends on voluntary donation behavior from citizens. Accordingly, it is important to consider ways to increase donation intention to build up organizational capability in terms of financial resources. Therefore, the competition for donations has highly increased so that fundraising techniques have been developed further to promote donation behavior based on basic marketing concepts (Éva, 2010). Waters and Tindall (2011) argued that sharing and reporting on the development of work for which required donations are used is a way to build a trusting relationship and to improve institutional accountability.

\subsection{Financial Sustainability}

Empirical literature has researched how to achieve the financial sustainability of nonprofit organizations. From an organizational management perspective, it is to increase the organizational efficiency and effectiveness in conducting business (Chetkovich \& Frumkin, 2003) and to satisfy the expectations of funders (LeRoux, 2009). Kingma (1993) applied modern portfolio theory to define financial sustainability of nonprofit organizations with revenue diversification and financial stability. It helps improve the independence of organizations in case of financial instability resulting from resource dependency (Froelich, 1999; Tinkelman, 1999), even though the nature of nonprofits can be shown as relying on donor voluntary contributions (Carroll \& Stater, 2008). Furthermore, considering the timeframe of financial capability, it is resilient to economic volatility in the short term and carries out the mission of the nonprofit in a sustainable manner in the long term (Bowman, 2011).

\section{Hypothesis Development}

To analyze what determines donation intention in response to television fundraising campaigns, five distinctive factors are identified: emotional sympathy, economic value, accountability, relevance, and sustainability. Considering different contents of fundraising campaign, this study selected five cases including natural disaster, hunger, disease, lack of education, and sanitation in line with the criteria of SDGs. To examine the effect of previous donation, this study classified respondents as experienced and inexperienced donors.

\subsection{Emotional Sympathy Factor}

Empirical studies have shown that sympathy based on emotional stimuli such as guilt or empathy may influence the giving behavior of donors (Clary \& Snyder, 1991). Accordingly, traditional fundraisers focused on inspiring potential donors to be willing to give through images that trigger emotional responses (Babin \& Darden, 1998). Emotions have significant impacts on intention and decision to donate, and it has shown that it is rather difficult for donors to decide their donation when emotional factors are entirely excluded (Faseur \& Geuens, 2012; Polonsky \& Sargeant, 2007). Andreoni (2006) argued that donors who are encouraged to donate by sympathy perceive the emotional utility as a benefit of donation. When donors encounter fundraising campaigns that inspire emotional sympathy and show distressing realities, they try to counteract through their giving behavior (Merchant, Ford, \& Sargeant, 2010) based on their expectations of social justice (Lerner, 1975). Bennett (2015) noted that donors show positive behaviors of giving in regard to emotional fundraising campaigns. Therefore, this study hypothesized the effects of emotional sympathy on donation intention (H1) and in response to five different contents of fundraising campaign in line with the criteria of SDGs for experienced donors ( $\mathrm{H} 1 \mathrm{a} \sim \mathrm{e})$ and inexperienced donors (H1f j j).

H1: Emotional sympathy affects donation intention in response to television fundraising campaigns.

H1a $\mathbf{j}$ : Emotional sympathy affects donation intention in response to television fundraising campaigns about natural disaster, hunger, diseases, lack of education, and sanitation.

\subsection{Economic Value Factor}

In terms of social marketing for the nonprofit sector, "price" is the cost of achieving what organizations set as their program goal and the amount of donations that encourages donors to pay (Aboramadan, 2018). The price of giving was defined by Weisbrod and Dominguez (1986) as the amount a donor contributes for the future output generated by an organization. What matters is the extent to which donors perceive the price of giving to be economically valuable (Wiepking \& Breeze, 2012). Bridgeland, McNaught, Reed, and Dunkelman (2009) suggested that nonprofit organizations that established 
greater financial efficiency in their program operations were able to attract more donations. Therefore, donors will determine their giving behavior based on how reasonable or acceptable they find the price of the product or services to be offered by nonprofits. Therefore, this study hypothesized the effects of economic value on donation intention $(\mathrm{H} 2)$ and in response to five different contents of fundraising campaign in line with the criteria of SDGs for experienced donors (H2a $\sim \mathrm{e})$ and inexperienced donors $(\mathrm{H} 2 \mathrm{f} \sim \mathrm{j})$.

H2: Economic value affects donation intention in response to television fundraising campaigns.

H2a $\mathbf{j}$ : Economic value affects donation intention in response to television fundraising campaigns about natural disaster, hunger, diseases, lack of education, and sanitation.

\subsection{Accountability Factor}

Considering the unique characteristics of the nonprofit sector, organizational accountability counts on the performance measurement (Poole, Nelson, Carnahan, Chepenik, \& Tubiak, 2000; Nguyen \& Tu, 2020; Nguyen, Duone, Tran, Ha, \& Phung, 2020). When a nonprofit requests a donation, donors expect the organization to demonstrate how reliable they are in managing financial resources and administrating for the purposes of soliciting the funds (Glaser, 1994; Sargeant \& Lee, 2004). As nonprofit organizations are required to prove their organizational accountability, Carman and Fredericks (2008) tried to define evaluation criteria in terms of verifying transparency in accounting operations and informing donors. Sloan (2009) stated that the accountability of the nonprofit sector can be based on how well an organization performs its business while meeting fiscal and ethical codes of conduct. In order to improve the reputation and the perceived quality of services, organizational accountability is important to be monitored and certified (Becker, 2018). The goal of constructing nonprofit accountability is to promote better donation behavior and ultimately build public trust in organizational consistency of financial operations and governance (Carman \& Fredericks, 2008). Therefore, this study hypothesized the effects of accountability on donation intention (H3) and also aligned with the five SDGs in the case of experienced donors (H3a $\sim$ e) and inexperienced donors (H3f j $)$.

H3: Accountability affects donation intention in response to television fundraising campaigns.

H3a e: Accountability affects donation intention in response to television fundraising campaigns about natural disaster, hunger, diseases, lack of education, and sanitation.

\subsection{Relevance Factor}

Empirical studies suggested that donors are more open to engaging with nonprofit organizations that can contribute to what donors care about and where donors perceive their communities to be (Kelly, 1991; Philipp, 1999). Considering that donors put their donations for nonprofit fundraising to addressing the issues of global poverty, donors want to make sure that their donations can contribute to changing realities (Worth, 2002). Klein (2009) stated that donors decide to give based on a "giving to a cause" principle in fundraising campaigns due to natural disasters. Studies have indicated that the stronger the need for help, the more people want to provide it (Staub \& Baer, 1974; Wagner \& Wheeler, 1969). In terms of "awareness of need," how donors perceive the need for help also plays a critical role in determining donation behavior (Bekkers \& Wiepking, 2011; Lee \& Farrell, 2003). By showing how funds will be relevantly used for the cause of poverty, nonprofit organizations provide the rationale that allows donors to evaluate how much their donations are needed (Johnston, 2002). Accordingly, clarifying the impact of donations is one of important strategies of fundraising to increase donation behavior (Waters \& Tindall, 2011). Therefore, this study hypothesized the effects of relevance on donation intention (H4) and also aligned with the five SDGs in the case of experienced donors (H4a e) and inexperienced donors $(\mathrm{H} 4 \mathrm{f} \sim \mathrm{j})$.

H4: Relevance affects donation intention in response to television fundraising campaigns.

H4a $\sim$ : Relevance affects donation intention in response to television fundraising campaigns about natural disaster, hunger, diseases, lack of education, and sanitation.

\subsection{Sustainability Factor}

According to Weerawardena, McDonald, and Mort (2010), sustainability in nonprofit organizations will be determined by how efficient and effective they are, rather than just the fact that they continue to bring its budget sources. What matters is the effectiveness of problemsolving with beneficiary-centered performance beyond whether the organization can maintain its existence. With regard to the performance (Firman, Mustapa, Ilyas, \& Purta, 2020; Lee \& Kim, 2019; Pinto, 2019) of nonprofits contributing to improve poverty in the long term, when it comes to operating their fieldwork, nonprofit organizations put their attention on beneficiaries who are their main clients, but when communicating with donors, sharing information about beneficiary-centered outcomes is insufficient (Campbell, 2010). In designing a fundraising campaign, nonprofits put more emphasis on inspiring donors in terms of their giving decisions, overlooking whether the campaign is having a sustainable impact of its performance on beneficiaries (Chetkovich \& Frumkin, 2003; McDonald, 2007). Therefore, this study hypothesized the 
effects of sustainability (Choi, Kim, \& Kim, 2019) on donation intention (H5) and also aligned with the five SDGs in the case of experienced donors (H5a e) and inexperienced donors $(\mathrm{H} 5 \mathrm{f} \sim \mathrm{j})$.

H5: Sustainability affects donation intention in response to television fundraising campaigns.

H5a j: Sustainability affects donation intention in response to television fundraising campaigns about natural disaster, hunger, diseases, lack of education, and sanitation.

\section{Methodology}

This study explored the determinants of donation intention in response to television fundraising campaigns of nonprofit organizations showing five cases in line with the criteria of SDGs. An online survey was conducted to randomly selected samples those who are previously exposed to television fundraising campaigns and potentially participate in donations. This study distributed surveys to those age of 20 or higher and diverse nationalities. The questionnaire was written in two versions, Korean and English, allowing participants to choose and respond according to their convenience. The validity of the questionnaire between the two versions was verified by back translation. The purpose of the study was explained to the participants, and the privacy and anonymity of the data were addressed. A screening question was asked as to whether respondents have ever seen television fundraising campaigns before. According to previous donation experienced, it classified respondents as experienced donors and inexperienced donors. Among the respondents, 66.5\% have previously participated in donation and $33.0 \%$ have not donated to a nonprofit organization. The survey was distributed to 271 people, and a total of 205 responses were collected with response rate of $75.6 \%$. Of the 205 respondents, $55 \%$ were female. The mean average age of the respondents was 41 years. Table 2 summarizes the demographics of the respondents.

The questionnaire included the captured images of television fundraising campaigns broadcasted on national television channels, providing five examples of campaigns for natural disaster, hunger, disease, lack of education, and sanitation respectively. Selected fundraising campaigns are corresponding to the criteria of SDGs as well. Given the ethical concerns with designing the questionnaire, extreme contents of fundraising campaigns were excluded. This study also excluded the names and logos of nonprofit organizations in the campaign contents. To set the reliability of the questionnaire with the captured images, this study checked Cronbach's alpha. Cronbach's alpha for natural disaster was 0.934 , hunger was 0.894 , disease was
0.932, lack of education was 0.936 , and sanitation was 0.946 .

Table 1: Summary of Demographics

\begin{tabular}{|c|c|}
\hline Demographics & $\%$ \\
\hline Gender & \\
Male & $44.4 \%$ \\
Female & $55.6 \%$ \\
\hline Age & \\
21-25 years old & $12.2 \%$ \\
26-30 years old & $17.7 \%$ \\
31-35 years old & $6.3 \%$ \\
36-40 years old & $5.9 \%$ \\
41-45 years old & $7.8 \%$ \\
46-50 years old & $9.8 \%$ \\
51-55 years old & $13.2 \%$ \\
56-60 years old & $12.2 \%$ \\
61-65 years old & $13.2 \%$ \\
66-70 years old & $1.5 \%$ \\
71 years or older & $1 \%$ \\
\hline Education & \\
High school & $22 \%$ \\
College degree (2 years) & $9.8 \%$ \\
Bachelor's degree (4 years) & $45.9 \%$ \\
Master's degree & $20 \%$ \\
Ph.D. & $2.4 \%$ \\
\hline Employment & \\
Student & $19.5 \%$ \\
Full-time employed & $36.6 \%$ \\
Part-time employed & $8.3 \%$ \\
Working without pay (volunteer) & $1.5 \%$ \\
Unemployed & $1 \%$ \\
Home duties & $3.9 \%$ \\
Retired & $15.1 \%$ \\
\hline Other & \\
\hline & \\
\hline & \\
\hline & \\
\hline & \\
\hline & \\
\hline
\end{tabular}

To examine the internal construct of determinants, in the case of data for experienced donors, Cronbach's alpha for emotional sympathy was 0.881 , economic value was 0.854 , accountability was 0.926 , relevance was 0.798 , and sustainability was 0.806 . In the case of data for inexperienced donors, Cronbach's alpha for emotional sympathy was 0.903 , economic value was 0.825 , accountability was 0.897 , relevance was 0.835 , and sustainability was 0.928 .

\section{Data Analysis}

This study applied factor analysis to check the validity of the determinants of donation intention in response to different contents of fundraising campaign. This study applied principal components as the extraction method with a Varimax rotation of Kaiser Normalization. The results of factor analysis represented the major determinants with Eigen values greater than 1.00. This study conducted factor analyses separately for data based on experience of 
participation in donation. To test how significantly determinants affect donation intention, regression analysis was applied to test the hypotheses using factor scores. Table 2 summarizes the results of multiple regression analysis for determinants influence donation intention for both experienced donors and inexperienced. Overall, the ANOVA analysis showed that the model was significant at 0.01 level with $F=26.540(r$-square $=0.513)$. In case of experienced donors, perceived emotional sympathy and sustainability for beneficiaries affect their donation intentions that support $\mathrm{H} 1$ and H5. For inexperienced donors, emotional sympathy affects their donation intention. Therefore, regardless of previous donation experiences, emotional sympathy has the greatest impact on donation intentions, and experienced donors consider long-term effects for beneficiaries.

Table 2: Effects of Determinants on Donation Intention

\begin{tabular}{|c|c|c|}
\hline \multirow{2}{*}{ Variables } & \multicolumn{2}{|c|}{ Standardized Coefficient(Sig) } \\
\cline { 2 - 3 } & $\begin{array}{c}\text { Experienced } \\
\text { Donors }\end{array}$ & $\begin{array}{c}\text { Inexperienced } \\
\text { Donors }\end{array}$ \\
\hline $\begin{array}{c}\text { Emotional } \\
\text { Sympathy (H1) }\end{array}$ & $0.636(* * *)$ & $0.587(* * *)$ \\
\hline $\begin{array}{c}\text { Economic Value } \\
\text { (H2) }\end{array}$ & 0.068 & 0.240 \\
\hline Accountability (H3) & 0.028 & 0.213 \\
\hline Relevance (H4) & 0.100 & 0.081 \\
\hline Sustainability (H5) & $0.334(* * *)$ & 0.239 \\
\hline
\end{tabular}

*** Significant at 0.01

This study also analyzed according to different contents of fundraising campaigns including natural disaster, hunger, disease, lack of education, and sanitation which are aligned with the criteria of SDGs respectively. Table 3 summarizes the results of the effects of determinants on donation intention for experienced and inexperienced donors in response to television fundraising campaigns. Overall, the results showed that experienced donors are dominantly affected by emotional sympathy for their giving behaviors, accepted H1a e. Additionally, in case of campaign about hunger, experienced donors consider how their donations will meet the demands of beneficiaries that approved H4b. For campaign on lack of education, experienced donors look at how well their donation will be spent, supported $\mathrm{H} 2 \mathrm{~d}$. In case of inexperienced donors, economic value of their donation was the most influencing determinant for their donation intention, supported $\mathrm{H} 2 \mathrm{f} \sim \mathrm{j}$. Inexperienced donors are affected by emotional sympathy in term of fundraising for hunger and disease.

This study found that people with previous donation experiences put more weights to decide their giving behavior. In the absence of a donation experience, people focus on how valuable their donation will be used for beneficiaries. Once they become experienced donors, donation intention is mainly affected by emotionally appealing contents of fundraising campaigns. In addition, as the topic of campaigns varies, respondents showed different considerations to decide their donation. Overall, organizational accountability and sustainability couldn't make significant impact on donation intention.

Table 3: Effects of Determinants on Donation Intention aligned with SDGs Criteria

\begin{tabular}{|c|c|c|}
\hline \multirow{2}{*}{ Variables } & \multicolumn{2}{|c|}{ Standardized Coefficient (Sig) } \\
\hline & Experienced Donors & Inexperienced Donors \\
\hline $\begin{array}{l}\text { Natural Disaster } \\
\text { Emotional } \\
\text { Sympathy } \\
\text { Economic Value } \\
\text { Accountability } \\
\text { Relevance } \\
\text { Sustainability }\end{array}$ & $\begin{array}{c}0.562(* * *) \\
0.007 \\
0.034 \\
0.051 \\
0.000 \\
\end{array}$ & $\begin{array}{c}0.135 \\
\\
0.455(* * *) \\
0.014 \\
0.140 \\
0.038\end{array}$ \\
\hline $\begin{array}{c}\text { Hunger } \\
\text { Emotional } \\
\text { Sympathy } \\
\text { Economic Value } \\
\text { Accountability } \\
\text { Relevance } \\
\text { Sustainability }\end{array}$ & $\begin{array}{c}0.666(* * *) \\
0.011 \\
0.060 \\
0.233(*) \\
0.018\end{array}$ & $\begin{array}{c}0.431(* * *) \\
0.404(* * *) \\
0.174 \\
0.055 \\
0.077\end{array}$ \\
\hline $\begin{array}{c}\text { Disease } \\
\text { Emotional } \\
\text { Sympathy } \\
\text { Economic Value } \\
\text { Accountability } \\
\text { Relevance } \\
\text { Sustainability }\end{array}$ & $\begin{array}{c}0.682(* * *) \\
0.087 \\
0.072 \\
0.095 \\
0.145\end{array}$ & $\begin{array}{c}0.248\left(^{*}\right) \\
0.400(* * *) \\
0.170 \\
0.049 \\
0.137\end{array}$ \\
\hline $\begin{array}{c}\text { Lack of } \\
\text { Education } \\
\text { Emotional } \\
\text { Sympathy } \\
\text { Economic Value } \\
\text { Accountability } \\
\text { Relevance } \\
\text { Sustainability }\end{array}$ & $\begin{array}{c}0.579(* * *) \\
0.190(* *) \\
0.011 \\
0.114 \\
0.175\end{array}$ & $\begin{array}{c}0.225 \\
0.520(* * *) \\
0.203 \\
0.166 \\
0.171\end{array}$ \\
\hline $\begin{array}{c}\text { Sanitation } \\
\text { Emotional } \\
\text { Sympathy } \\
\text { Economic Value } \\
\text { Accountability } \\
\text { Relevance } \\
\text { Sustainability }\end{array}$ & $\begin{array}{c}0.561(* * *) \\
0.111 \\
0.053 \\
0.046 \\
0.209\end{array}$ & $\begin{array}{c}0.061 \\
0.324(*) \\
0.145 \\
0.085 \\
0.121\end{array}$ \\
\hline
\end{tabular}

*** Significant at $0.01 ; *$ Significant at 0.1

\section{Conclusion}

\subsection{Findings}

This study aims to analyze the determinants of donation intention in response to television fundraising campaigns of 
nonprofit organizations. The determinants are selected to measure how donors can be motivated in their giving intentions when a nonprofit organization solicits the financial contribution. Previous studies on donation intention have rarely examined the impact of the content of television fundraising campaigns produced by nonprofit organizations. This study filled the gap by revealing the predictor variables of donation intention especially associated with television fundraising campaigns about different topics of poverty issues aligned with the criteria of SDGs. Especially, to clarify the difference in perceiving fundraising campaign according to donation experiences, this study divided respondents into two groups, experienced donors and inexperienced donors.

Regardless of the contents of fundraising campaigns, this study first analyzed the donation intention according to overall television fundraising campaign. Apart from the donation experience, all respondents were influenced to show their donation intention according to the extent of emotional sympathy caused by the fundraising campaign. This indicates that donors contribute in nonprofits on the basis of emotional empathy appealed by the reality of poverty apart from previous experience. Experienced donors also consider how sustainable their financial contribution can be managed for beneficiaries that accepted H5. It is notable that there is a difference in the view of perceiving the television fundraising campaigns according to the donation experience. The intention to donate was insignificant about economic value of donation, accountability of nonprofit organizations, and relevance of program operation for beneficiaries that rejected $\mathrm{H} 2, \mathrm{H} 3$, and $\mathrm{H} 4$ apart from donation experience. This illustrates that it does not influence on donors' decision in giving intentions.

This study also classified effects for both groups with respect to the five cases of fundraising campaigns aligned with criteria of SDGs. First, emotional sympathy appears to be the most significant determinant in all case of problem situations for experienced donors. Therefore, H1a e were accepted. In case of fundraising campaign about hunger, experienced donors consider whether their donations would be used to meet the needs of the actual beneficiaries. Therefore, H4b was accepted. Second, for inexperienced donors, the greatest impact on their intention to donate for all types of fundraising campaigns was economic value. Emotional sympathy also affected their intention regarding hunger and disease-related campaign. Therefore, $\mathrm{H} 2 \mathrm{f} \sim \mathrm{j}$ were accepted. This study also found that overall effects were stronger with experienced donors rather than inexperienced donors.

There were distinctive differences in exhibiting donation intention according to previous experience. Experienced donors realized their intention to donate based on how emotionally convinced by the content of fundraising campaign, while inexperienced donors more consider how their donation would be economically valuable. Experienced donors showed significant effects of economic value on intention in the case of lack of education and effects of relevance on intention in the case of hunger. Inexperienced donors showed significant effects of emotional sympathy on intention in the case of disease. Results implied how fundraising campaigns provide intentions differ based on existence of experiences and perceived contents of campaigns.

\subsection{Managerial Implications}

This study provides managerial implications. This study provides implications to fundraising organizations as to which aspects need to be addressed to draw motivation, as effects of determinants on donation intention were different. When designing a fundraising campaign to attract new donors and expand the donor pool, it is important to deliver how well the donors' contribution will be valued in the field. The results of this study demonstrated that managerial aspects such as accountability and relevance were less weighted in the intention level of donors. It indicates that organizational performances are undervalued in terms of donors' intentions. Since fundraising campaigns focus primarily on which organizations will do what to solve or improve, while donors hardly perceive information about accountability. Also, if donors are not well aware of external audits or internal procedures to increase organizational accountability, it is difficult to influence donation intentions (Becker, 2018). In terms of the relevance, it may be necessary for the donors to have previously earned knowledge in determining how relevant the project is to solve the problem of poverty. For example, to solve a health problem in a village suffering from malaria, donors may need more than the information available from fundraising campaigns to determine which method is appropriate to solve the problem. Consideration may be given to the difficulty for donors in determining institutional credibility and business adequacy based on the information provided in fundraising advertising.

Nonprofit fundraising campaigns are often used as a communication channel to represent the reality of poverty (Gourville \& Rangan, 2004). It can be used to effectively inform the role of nonprofit organizations in society and to actively encourage the participation of ordinary citizens (Brown \& Kalegaonkar, 2002). Consequently, how well organized the nonprofit sector communicate with the general public will in return provides a foundation for institutional sustainability (Iwu, Kapondoro, Darko, \& Tengeh, 2015). If nonprofit organizations disregard the function of their fundraising campaigns for information 
transfer and blindly focus on raising funds based on methods such as the shock effect, it will not be helpful considering the influential presence of the organizations in the long term (Ong, 2015). As results showed, better strategies based on different SDGs criteria should be applied to evoke donation intentions. Sustainable development is possible through innovative efforts (Leach et al., 2012) and must overcome the limitations of the traditional techniques used for fundraising for centuries, which are overly dependent on emotional appeals. As it becomes more complex in identifying the motives of donors for making donations, the importance of strategically encouraging donation behavior should be highlighted (Eikenberry, 2009).

\subsection{Policy Implications}

Nonprofit organizations have made major strides in the field of international development beyond political relations between states and the authorities of decision-making from intergovernmental organizations. The results of the study will analytically suggest that nonprofit organizations could consider and develop more effective strategies for financial sustainability by designing donor-focused fundraising. Moreover, television fundraising campaigns, which are well organized to bring financial resources for organizations and to provide a better understanding of poverty, will ultimately enable the public to recognize that the universal goal is to pursue a sustainable world for everyone. In the long term, this will build up the common discourse that everyone is aware of the mutual responsibility to be involved in international development with a sense of global citizenship.

Nonprofit organizations have evolved remarkably, encouraging citizens to voluntarily participate in areas not covered by governments or businesses. Especially considering the calls for the implementation of the SDGs, this research puts more weight on active engagement of the nonprofit sector. Nonprofit organizations can not only build citizen participation in donation intentions by showing the reality of the fields, but also illustrate further through its institutional experiences and knowledge in order to form and improve public awareness in the targeted areas of SDGs. Organizations can expand the influence of its implementation by utilizing the media to promote donation behavior of the public (Bowen, Kahindi, \& Herremans, 2010). Ultimately, active involvement of the public will play a decisive role in achieving the development agendas within the targeted time. This study provides implications to design effective fundraising campaigns for increasing giving intentions of donors and to ensure the financial sustainability of nonprofit organizations and thereby to enhance public awareness for more successful implementation of SDGs.

\subsection{Additional Findings}

To find out whether intention for donation intentions differs based on prior experiences of donation, this study conducted an independent samples $t$-test. The results showed that there is a difference in determining donation intention with fundraising campaigns based on experiences. ANOVA analysis on demographics showed that donation intentions differ by age groups and the level of education.

\subsection{Limitations and Future Research}

Future research will increase sample size and might look into different types of media. Further studies may need to be supported by in-depth qualitative research to analyze the factors that determine donation intentions.

\section{References}

Aboramadan, M. (2018). NGOs Management: A Roadmap to Effective Practices. Journal of Global Responsibility, 9(4), 372-387.

Aldrich, T. (2004). Do-it-yourself DRTV: A Practical Guide to Making Direct Response Television Advertising Work for Charities. International Journal of Nonprofit and Voluntary Sector Marketing, 9(2), 135-144

Andreasen, A. R., Kotler, P., \& Parker, D. (2008). Strategic Marketing for Nonprofit Organizations. Upper Saddle River, NJ: Pearson/Prentice Hall. 44-53.

Andreoni, J. (2006). Philanthropy. Handbook of The Economics of Giving, Altruism and Reciprocity, 2, 1201-1269.

Baberini, M., Coleman, C. L., Slovic, P., \& Västfjäll, D. (2015). Examining the Effects of Photographic Attributes on Sympathy, Emotions, and Donation Behavior. Visual Communication Quarterly, 22(2), 118-128.

Babin, B. J., Darden, W. R., \& Babin, L. A. (1998). Negative Emotions in Marketing Research: Affect or Artifact? Journal of Business Research, 42(3), 271-285.

Bae, J., Kim, B., \& Oh, S. (2019). The Effects of Purchase Intention of Oriental Medicien Cosmetics on Selection and Brand Asset Attributes. Journal of Distribution Science, 17(1), 73-87.

Bekkers, R., \& Wiepking, P. (2011). A Literature Review of Empirical Studies of Philanthropy: Eight Mechanisms That Drive Charitable Giving. Nonprofit and Voluntary Sector Quarterly, 40(5), 924-973.

Becker, A. (2018). An Experimental Study of Voluntary Nonprofit Accountability and Effects on Public Trust, Reputation, Perceived Quality, and Donation Behavior. Nonprofit and Voluntary Sector Quarterly, 47(3), 562-582.

Bennett, R. (2015). Individual Characteristics and the Arousal of Mixed Emotions: Consequences for the Effectiveness of Charity Fundraising Advertisements. International Journal of Nonprofit and Voluntary Sector Marketing, 20(2), 188-209.

Bowen, F., Newenham-Kahindi, A., \& Herremans, I. (2010). 
When Suits Meet Roots: The Antecedents and Consequences of Community Engagement Strategy. Journal of Business Ethics, 95(2), 297-318.

Bowman, W. (2011). Financial Capacity and Sustainability of Ordinary Nonprofits. Nonprofit Management and Leadership, 22(1), 37-51.

Bridgeland, J. M., McNaught, M., Reed, B., \& Dunkelman, M. (2009). The Quiet Crisis: The Impact of the Economic Downturn on the Nonprofit Sector. W.K. Kellogg Foundation. Retrieved March 30, 2019 from https://www.issuelab.org/resource/the-quiet-crisis-the-impactof-the-economic-downturn-on-the-nonprofit-sector.html

Brooker, P., Vines, J., Sutton, S., Barnett, J., Feltwell, T., \& Lawson, S. (2015). Debating Poverty Porn on Twitter: Social Media as A Place for Everyday Socio-Political Talk. In Proceedings of the 33rd Annual ACM Conference, 3177-3186.

Brown, L. D., \& Kalegaonkar, A. (2002). Support Organizations and the Evolution of the NGO Sector. Nonprofit and Voluntary Sector Quarterly, 31(2), 231-258.

Čačija, N. L. (2013). Fundraising in the Context of Nonprofit Strategic Marketing: Toward a Conceptual Model. Management: Journal of Contemporary Management Issues, 18(1), 59-78.

Campbell, D. A. (2010). Is Constituent Feedback Living up to Its Promise? Provider Perceptions of Feedback Practices in Nonprofit Human Service Organizations. Families in Society, 91(3), 313-320.

Carman, J. G., \& Fredericks, K. A. (2008). Nonprofits and Evaluation: Empirical Evidence from the Field. New Directions for Evaluation, 2008(119), 51-71.

Carroll, D. A., \& Stater, K. J. (2009). Revenue Diversification in Nonprofit Organizations: Does It Lead to Financial Stability? Journal of Public Administration Research and Theory, 19(4), 947-966.

Casey, J. (2016). Comparing Nonprofit Sectors Around the World. Journal of Nonprofit Education and Leadership, 6(3), 187-223.

Chetkovich, C., \& Frumkin, P. (2003). Balancing Margin and Mission: Nonprofit Competition in Charitable Versus FeeBased Programs. Administration \& Society, 35(5), 564-596.

Choi, C. Kim, C., \& Kim, C. (2019). Towards Sustainable Environmental Policy and Management in the Fourth Industrial Revolution: Evidence from Big Data Analytics. Journal of Asian Finance, Economics, and Business, 6(3), 185-192.

Clary, E. G., \& Snyder, M. (1991). A Functional Analysis of Altruism and Prosocial Behavior: The Case of Volunteerism. Review of Personality and Social Psychology, 12, 119-148.

Erlandsson, A., Nilsson, A., \& Västfjäll, D. (2018). Attitudes and Donation Behavior When Reading Positive and Negative Charity Appeals. Journal of Nonprofit \& Public Sector Marketing, 30(4), 444-474.

Eikenberry, A. M. (2009). Refusing the Market: A Democratic Discourse for Voluntary and Nonprofit Organizations. Nonprofit and Voluntary Sector Quarterly, 38(4), 582-596.

Éva, K. (2010). The Need for a Comprehensive Fund Raising Approach. Advances in Management, 3(2), 26-32.

Faseur, T., \& Geuens, M. (2012). On the Effectiveness of Ego-and other-focused ad-evoked Emotions: The moderating Impact of Product Type and Personality. International Journal of
Advertising, 31(3), 529-546.

Firman, A., Mustapa, Z., Ilyas, G. B., Purta, A. H. P. K. (2020). Relationship of TQM on Managerial Performance: Evidence from Property Sector in Indonesiz. Journal of Distribution Science, 18(1), 47-57.

Froelich, K. A. (1999). Diversification of Revenue Strategies: Evolving Resource Dependence in Nonprofit Organizations. Nonprofit and Voluntary Sector Quarterly, 28(3), 246-268.

Glaser, J. S. (1994). The United Way Scandal: An Insider's Account of What Went Wrong and Why (Vol. 22). New Jersey, NJ: John Wiley \& Sons Inc.

Gourville, J. T., \& Rangan, V. K. (2004). Valuing the Cause Marketing Relationship. California Management Review, 47(1), 38-57.

Iwu, C., Kapondoro, L., Twum-Darko, M., \& Tengeh, R. (2015). Determinants of Sustainability and Organisational Effectiveness in Non-Profit Organisations. Sustainability, 7(7), 9560-9573.

Johnston, M. (2002). Evaluating Online Fundraising Success. Fundraising on the Internet, 39-46. San Francisco, CA: Jossey-Bass.

Keith, S. \& Roger, B. (1993). Defining the Role of Nonprofit Corporations in Community Economic Development. Journal of the Community Development Society, 23(2), 213-228.

Kelly, K. S. (1991). Fund Raising and Public Relations: A Critical Analysis. Hillsdale, NJ: Lawrence Erlbaum Associates.

Kingma, B. R. (1993). Portfolio Theory and Nonprofit Financial Stability. Nonprofit and Voluntary Sector Quarterly, 22(2), 105-119.

Klein, K. (2009). Reliable Fundraising in Unreliable Times: What Good Causes Need to Know to Survive and Thrive. San Francisco, CA: Jossey-Bass.

Krugman, H. E. (1965). The Impact of Television Advertising: Learning without Involvement. Public Opinion Quarterly, 29(3), 349-356.

Leach, M., Rockström, J., Raskin, P., Scoones, I. C., Stirling, A. C., Smith, A., Thimpson, J., Millstone, E., Around, E., Folke, C., \& Olsson, P. (2012). Transforming Innovation for Sustainability. Ecology and Society, 17(2), 11.

Lee, B. A., \& Farrell, C. R. (2003). Buddy, Can You Spare A Dime? Homelessness, Panhandling, and the Public. Urban Affairs Review, 38(3), 299-324.

Lee, C., \& Kim, J. (2019). The Management Performance of Food Service Startups in Traditional Market. Journal of Distribution Science, 17(12), 95-103.

Leighann. N., Francois. B., \& Anahit A. (2012). Fundraising Methods: Past, Present, Future. SCSE-CSES Research Report, SPROTT Centre for Social Enterprises. Retrieved August 17, 2019 from https://sprott.carleton.ca/wpcontent/uploads/Paper1charitiesfundraisingpastpresentfutureL NFBAA20121031.pdf

Lerner, M. J. (1975). The Justice Motive in Social Behavior: Introduction. Journal of Social Issues, 31(3), 1-19.

LeRoux, K. (2009). Managing Stakeholder Demands: Balancing Responsiveness to Clients and Funding Agents in Nonprofit Social Service Organizations. Administration \& Society, 41(2), 158-184.

Lindahl, W. E., \& Conley, A. T. (2002). Literature Review: Philanthropic Fundraising. Nonprofit Management and 
Leadership, 13(1), 91-112.

McDonald, R. E. (2007). An Investigation of Innovation in Nonprofit Organizations: The Role of Organizational Mission. Nonprofit and Voluntary Sector Quarterly, 36(2), 256-281.

Merchant, A., Ford, J. B., \& Sargeant, A. (2010). Charitable Organizations' Storytelling Influence on Donors' Emotions and Intentions. Journal of Business Research, 63(7), 754-762.

Nguyen, K. T., Duong, T. M., Tran, N. Y., Ha, A. T., \& Phung, N. T. (2020). The Impact of Emotional Intelligence on Performance: A Closer Look at Individual and Environmental Factors. Journal of Asian Finance, Economics, and Business, $7(1), 183-193$.

Nguyen, T. H., \& Tu, V. B. (2020). Social Responsibility, Organizational Commitment, and Organizational Performance: Food Processing Enterprises in the Mekong River Delta. Journal of Asian Finance, Economics, and Business, 7(2), 309-316.

Ong, J. C. (2015). Charity Appeals as Poverty Porn? Production Ethics in Representing Suffering Children and Typhoon Haiyan Beneficiaries in the Philippines. Retrieved March 10, 2019 from https://leicester.figshare.com/articles/Charity Appeals as Pov erty_Porn_Production_Ethics_in_Representing_Suffering_Chi ldren_and_Typhoon_Haiyan_Beneficiaries_in_the_Philippine $\mathrm{s} / 101 \overline{7} 204 \overline{2} / 1$

Phan, D. T. T., Nguyen, T. T. H., \& Bui, T. A. (2019). Going Beyong Border? Intention to Use International Bank Cards in Vietnam. Journal of Asian Finance, Economics, and Business, 6(3), 315-325.

Philipp, A. A. (1999). Community Foundations: Linking Donors to Communities. New Directions for Philanthropic Fundraising, 1999(23), 43-50.

Pinto, L. (2019). Social Supply Chain Practices and Companies Performance: An Analysis of Portuguese Industry. Journal of Distribution Science, 17(11), 53-62.

Polonsky, M. J., \& Sargeant, A. (2007). Managing the Donation Service Experience. Nonprofit Management and Leadership, 17(4), 459-476.

Poole, D. L., Nelson, J., Carnahan, S., Chepenik, N. G., \& Tubiak, C. (2000). Evaluating Performance Measurement Systems in Nonprofit Agencies: The Program Accountability Quality Scale (PAQS). American Journal of Evaluation, 21(1), 15-26.

Reiley, D., \& Samek, A. (2018). Round Giving: A Field Experiment on Suggested Donation Amounts in PublicTelevision Fundraising. Economic Inquiry, 57(2), 876-889.

Salamon, L. M., \& Anheier, H. K. (2015). SDGs and NPIs: Private Nonprofit Institutions-The Foot Soldiers for the UN Sustainable Development Goals. Baltimore: Johns Hopkins Center for Civil Society Studies.

Sargeant, A. \& Lee, S. (2004). Trust and Relationship Commitment in The United Kingdom Voluntary Sector: Determinants of Donor Behavior. Psychology \& Marketing, 21(8), 613-635.

Sloan, M. F. (2009). The Effects of Nonprofit Accountability
Ratings on Donor Behavior. Nonprofit and Voluntary Sector Quarterly, 38(2), 220-236.

Srnka, K. J., Grohs, R., \& Eckler, I. (2003). Increasing Fundraising Efficiency by Segmenting Donors. Australasian Marketing Journal, 11(1), 70-86.

Staub, E., \& Baer, R. S. (1974). Stimulus Characteristics of a Sufferer and Difficulty of Escape as Determinants of Helping. Journal of Personality and Social Psychology, 30(2), 279.

Teri, K. H. (2001). Integrated Marketing Communications for Local Nonprofit Organizations: Developing an Integrated Marketing Communications Strategy. Journal of Nonprofit and Public Sector Marketing, 9(1), 141-155.

Tinkelman, D. (1999). Factors Affecting the Relation Between Donations to Not-For-Profit Organizations and an Efficiency Ratio. Research in Government and Nonprofit Accounting, 10(1), 135-161.

Wagner, C., \& Wheeler, L. (1969). Model, Need, and Cost Effects in Helping Behavior. Journal of Personality and Social Psychology, 12(2), 111.

Waters, K. (1998). How World Vision Rose from Obscurity to Prominence: Television Fundraising, 1972-1982. American Journalism. 15(4), 69-93.

Waters, R. D. (2011). Increasing Fundraising Efficiency Through Evaluation: Applying Communication Theory to the Nonprofit Organization-Donor Relationship. Nonprofit and Voluntary Sector Quarterly, 40(3), 458-475.

Waters, R. D., \& Tindall, N. T. (2011). Exploring the Impact of American News Coverage on Crisis Fundraising: Using Media Theory to Explicate A New Model of Fundraising Communication. Journal of Nonprofit \& Public Sector Marketing, 23(1), 20-40.

Weerawardena, J., McDonald, R. E., \& Mort, G. S. (2010). Sustainability of Nonprofit Organizations: An Empirical Investigation. Journal of World Business, 45(4), 346-356.

Weisbrod, B. A., \& Dominguez, N. D. (1986). Demand for Collective Goods in Private Nonprofit Markets: Can Fundraising Expenditures Help Overcome Free-Rider Behavior? Journal of Public Economics, 30(1), 83-96.

Wiepking, P., \& Breeze, B. (2012). Feeling Poor, Acting Stingy: The Effect of Money Perceptions on Charitable Giving. International Journal of Nonprofit and Voluntary Sector Marketing, 17(1), 13-24.

Wolch, J. R. (1990). The Shadow State: Government and Voluntary Sector in Transition. Foundation Center.

Worth, M. J. (2002). New Strategies for Educational Fund Raising. Westport, CT: Rowman \& Littlefield Publishers.

Yörük, B. K. (2012). The Effect of Media on Charitable Giving and Volunteering: Evidence from the "Give Five" Campaign. Journal of Policy Analysis and Management, 31(4), 813-836.

Zheng, Y., \& McKeever, B. W. (2016). Communicating to Improve Health: Using Theory to Improve Fundraising for Health-Related Events. Nonprofit and Voluntary Sector Quarterly, 45(6), 1276-1296. 